\title{
PENYULUHAN KOMPETENSI KOMUNIKASI NON VERBAL BAGI MASYARAKAT DI DESA MEKARMUKTI, BANDUNG BARAT
}

\author{
Sri Seti Indriani ${ }^{1}$, Ditha Prasanti ${ }^{1 a}$
}

\begin{abstract}
Non-verbal communication is the delivery of messages without words and gives meaning to verbal communication, where non-verbal communication is older than verbal communication because since we were born we have done it until the age of about 18 months, such as touch, smile, crying eyes, and so on. Without us knowing we have practiced it, it is no wonder, if we doubt someone, we are more confident in the nonverbal message (probably from his movements). This shows how important we are to learn the knowledge of non-verbal communication. This is what underlies the author performs Community Service (PKM) with the title "Communication Non-Verbal Communication Competence for People in the village of Mekarmukti, West Bandung". This extension activity was conducted to the community in the village of Mekarmukti, district. West Bandung. Community Service Activities has the purpose to produce the following outcomes: 1) Providing concrete knowledge and insight about non-verbal communication and its current development to the community in Mekarmukti Village, West Bandung Regency; 2) Providing comprehensive knowledge and insight on non-verbal communication concepts, as well as good communication tips. Method of PKM implementation conducted in this extension activity is ice breaking method; lecture method; and feedback collection methods.
\end{abstract}

Keywords: Communication, Competence, Counseling, Non Verbal, West Bandung.

JURNAL PENGABDIAN PADA MASYARAKAT

Website: http://ojs.ejournal.id/index.php/ppm

Permalink: http://ojs.ejournal.id/index.php/ppm/article/view/109

How to cite (APA): Indriani, S. S., \& Prasanti, D. (2017). Penyuluhan kompetensi komunikasi non verbal bagi masyarakat di desa Mekarmukti, Bandung Barat. Jurnal Pengabdian Pada Masyarakat, 2(1), 62-74.

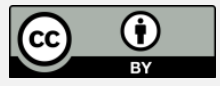

This is an open access article distributed under the terms of the Creative Commons Attribution 4.0 International License, which permits unrestricted use, distribution, and reproduction in any medium, provided the original work is properly cited.

\section{PENDAHULUAN}

Komunikasi non-vebal sering kali tidak diindahkan dalam berkomunikasi, seringkali komunikator lebih memusatkan diri pada komunikasi verbal, fokus terhadap apa yang dibicarakan atau dikatakan oleh seseorang tanpa melihat tanda-tanda lain yang berhubungan dengan komunikasi non-verbal. Pada era digital ini, dimana gaya hidup masyarakat jaman sekarang yang lebih tergantung dengan cara berkomunikasi melalui media sosial, melupakan dengan apa yang disebut sebagai komunikasi non-verbal.

\footnotetext{
${ }^{1}$ Fakultas IImu Komunikasi Universitas Padjajaran; rahadianindri@gmail.com.

a email: dithaprasanti@gmail.com.
} 
Seringkali kita menemukan banyak orang yang salah menafsirkan katakata seseorang dalam media sosial karena tidak diiring oleh komunikasi non-verbal, sering kita jumpai contoh-contoh terdapatnya friksi atau konflik yang terjadi dalam komunikasi media sosial hanya karena kita salah menafsirkan perkataan yang terdapat dalam layar media sosial. Hal ini disebabkan karena intonasi dan ekspresi muka tidak dapat diperlihatkan ketika kita berkomunikasi dalam media sosial.

Komunikasi non verbal adalah penyampaian pesan tanpa kata-kata dan memberikan arti pada komunikasi verbal, dimana komunikasi non verbal lebih tua daripada komuniasi verbal karena sejak kita dilahirkan telah melakukannya hingga usia sekitar 18 bulan, seperti sentuhan, senyuman, pandangan mata menangis dan sebagainya. Tanpa kita sadari kita telah mempraktekannya, maka tak heran, jika kita ragu akan seseorang, kita lebih percaya akan pesan nonverbalnya (mungkin dari gerak-geriknya). Orang yg terampil membaca pesan nonverbal disebut intuitif, sedang yg terampil mengirimkan disebut ekspresif.

Komunikasi nonverbal adalah komunikasi yang menggunakan pesanpesan nonverbal. Istilah nonverbal biasanya digunakan untuk melukiskan semua peristiwa komunikasi di luar kata-kata terucap dan tertulis. Secara teoritis, komunikasi nonverbal dan komunikasi verbal dapat dipisahkan. Namun dalam kenyataannya, kedua jenis komunikasi ini saling jalin menjalin, saling melengkapi dalam komunikasi yang kita lakukan seharihari.Mark L. Knapp (dalam Jalaludin, 1994), menyebut lima fungsi pesan nonverbal yang dihubungkan dengan pesan verbal:

1) Repetisi, yaitu mengulang kembali gagasan yang sudah disajikan secara verbal. Misalnya setelah mengatakan penolakan saya, saya menggelengkan kepala.

2) Substitusi, yaitu menggantikan lambang-lambang verbal. Misalnya tanpa sepatah katapun kita berkata, kita menunjukkan persetujuan dengan mengangguk-anggukkan kepala.

3) Kontradiksi, menolak pesan verbal atau memberi makna yang lain terhadap pesan verbal. Misalnya anda 'memuji' prestasi teman dengan mencibirkan bibir, seraya berkata, "Hebat, kau memang hebat."

4) Komplemen, yaitu melengkapi dan memperkaya makna pesan nonverbal. Misalnya, air muka anda menunjukkan tingkat penderitaan yang tidak terungkap dengan kata-kata. 
5) Aksentuasi, yaitu menegaskan pesan verbal atau menggarisbawahinya. Misalnya, anda mengungkapkan betapa jengkelnya anda dengan memukul meja.

Komunikasi non verbal ini lamban laun kehilangan fungsinya ketika manusia sudah mulai berkomuniasi dalam media sosial. Meskipun pada sekarang aplikasi-aplikasi chat dalam media sosial memfasilitasi gambargambar seperti emicon-emicon yang mengambarkan ekspresi atau perasaan seseorang, tetap komunikasi non verbal secara langsung dibutuhkan. Ada saatnya dimana dalam sebuah percakapan dalam media sosial, seseorang ketika mengungkapkan sesuatu selalu 'harus' menambahkan emicon yang sedang tersenyum, dan ketika tidak ditambahkan emicon tersebut, pihak lainnya merasa bahwa orang yang diajak berbicara itu sedang marah, kesel atau tidak mood, padahal itu belum tentu benar.

Meskuipun demikian pada hakekatnya media sosial sangat banyak manfaatnya dalam kehidupan masyarat sekarang, seperti paparan Harold D. Laswell mengenai fungsi media bisa dibagi menjadi tiga. Pertama, media memiliki fungsi sebagai pemberi informasi untuk publik luas tentang hal-hal yang berada di luar jangkauan penglihatan mereka. Kedua, media berfungsi melakukan seleksi, evaluasi, dan interpretasi atas informasi yang diperoleh. Ketiga, media berfungsi menyampaikan nilai dan warisan sosialbudaya kepada masyarakat (Haryatmoko, 2007). Gamble, Teri, dan Michael (2005) menyebutkan, media sosial mempunyai ciri-ciri sebagai berikut :

1) Pesan yang di sampaikan tidak hanya untuk satu orang saja namun bisa keberbagai banyak orang contohnya pesan melalui SMS ataupun internet

2) Pesan yang di sampaikan bebas, tanpa harus melalui suatu Gatekeeper

3) Pesan yang di sampaikan cenderung lebih cepat di banding media lainnya

4) Penerima pesan yang menentukan waktu interaksi

Komunikasi yang dilakukan dalam media sosial tidak selalu berjalan mulus sesuai dengan yang diinginkan para penggunanya, kesalahpahaman dalam komunikasi kerap terjadi mulai dari gaya bahasa yang tidak selalu memakai bahasa yang baku, atau bahasa yang sesuai dengan ejaan yang disempurnakan (EYD) bahasa Indonesia, hingga tidak dihiraukannya 
aspek-aspek non verbal. Hal ini memungkinkan friksi yang mungkin terjadi diantara pengguna media sosial sebagai aplikasi chat baik personal maupun kelompok yang menghasilkan sebuah komunikasi yang tidak efektif.

Ibu-ibu PKK desa mekarmukti merupakan ibu-ibu yang membangun sebuah komunitas tersendiri di desa mekarmukti, mereka merupakan ibuibu yang aktif dalam merancang berbagai aktivitas dalam masyarakat setempat. Ibu-ibu PKK ini kebanyakan merupakan ibu rumah tangga yag telah memiliki anak-anak remaja, dan bahkan beberapa dari mereka telah memiliki cucu namun tetap aktif dalam melakukan aktivitas desa. Mereka mengakui bahwa mereka mengunakan aplikasi media sosial mulai dari Black Berry Messenger (BBM), Whatsup messenger dan beberapa dari mereka memiliki akun Facebook. Mereka mengakui bahwa dalam berkomunikasi dengan sesama anggota ibu-ibu PKK ini mereka menggunakan BBM group atau Whatsup group. Selain itu, mereka juga menyadari bahwa anak-anak mereka memiliki pengetahuan lebih dalam bermedia sosial, maka itu mereka memiliki keinginan untuk mengetahui lebih dalam mengenai bermedia sosial dengan bener agar supaya mereka tetap bisa mengawasi anak-anak mereka. Tim dosen Fikom UNPAD memberikan semacam penyuluhan mengenai komunikasi non-verbal yang ternyata mendapatkan reaksi yang sangat baik dari ibu-ibu PKK, mereka baru menyadari bahwa komunikasi non verbal memiliki peran penting dalam berkomunikasi. Dengan penyuluhan yang dilakukan oleh Tim Dosen Fikom UNPAD ini mengenai komunikasi non-verbal, ibu-ibu PKK menjadi terbuka wawasannya bahwa komunikasi non-verbal tidak boleh diabaikan.

Secara sederhana, seperti yang dingkapkan Mulyana (2004) pesan nonverbal adalah semua isyarat yang bukan kata-kata. Larry A. Samovar dan Richard E. Porter, komunikasi non verbal mencakup semua rangsangan dalam suatu setting komunikasi (Mulyana, 2004). Melihat dari penjelasan tersebut, memungkinkan bahwa komunikasi non verbal merupakan komunikasi yang disengaja maupun tidak disengaja.Dengan komunikasi non-verbal meskipun kita tidak memiliki niat dalam berkomunikasi pada orang lain, namun dengan sendirinya sudah memberikan pesan kepada orang lain. Contohnya, ketika seseorang sedang duduk termenung sendirian, ia memberikan pesan pada orang yang melihatnya bahwa dia sedang sedih atau sedang memikirkan suatu masalah. 
Faktor-faktor nonverbal sangat menentukan makna dalam komunikasi interpersonal.

Mahrabian, penulis The Silent Message, bahkan memperkirakan $93 \%$ dampak pesan diakibatkan oleh pesan non verbal. Selain itu perasaan dan emosi seseorang kadang kala tidak dapat diperlihatkan melalui kata-kata, bahkan ada anggapan bahwa apabila anda sayang dengan seseorang perlihatkanlah dengan tindakan bukan kata-kata. Sehingga disimpulkan bahwa komunipesan dan emosi lebih cermat disampaikan dengan pesan nonverbal. Tidak heran jika Mahrabian (1967) menuturkan "Hanya $7 \%$ perasaan kasih sayang dapat dikomunikasikan dengan kata-kata. Selebihnya $38 \%$ lewat suara, dan 55\% dikomunikasikan melalui ungkapan wajah (senyum, kontak mata, dan sebagainya)"

Pesan nonverbal menyampaikan makna dan maksud yang relatif bebas dari penipuan, distorsi dan kerancuan. Kadang kala, seorang yang ahli dalam membaca gerakan tubuh, akan terlihat apakah orang tersebut mengatakan hal yang jujur atau tidak. Contohnya ketika seseorang yang sedang berbicara namun tanpa ia sadari ia terlihat gelisah dan berkata secara terbata-bata.Hudjana (2003:26) mendefinisikan komunikasi nonverbal sebagai penciptaan dan pertukaran pesan dengan tidak menggunakan kata-kata seperti komunikasi yang menggunakan gerakan tubuh, sikap, kontak mata, ekspresi muka, kedekatan jarak, dan sentuhan.

Memiliki kemampuan dalam komunikasi non verbal menjadi sangat ppenting ketika berkomunikasi dalam sebuah komunitas, komunitas menurut Wengner sebagaimana dibahas oleh Setiyani (2013) adalah sekelompok orang yang saling berbagi lingkungan, perhatian, masalah, serta memiliki keterkaitan atau kegemaran yang sama terhadap suatu topik. Ibu-ibu PKK di Desa Mekarmukti Kabupaten Bandung Barat merupakan sebuah komunitas karena memiliki keinginan yang sama dalam hal membangun masyarakat setempat dalam berbagai kegiatan dan aktifitas. Tanpa mereka sadari mereka sudah menggunakan komunikasi non-verbal namun kurang memiliki pemahaman betapa pentingnya komunikasi non verbal demi keefektifan berkomunikasi. Sehingga tim dosen Fikom UNPAD merasa memiliki tanggung jawab untuk memberikan wawasan dan kesadaran akan hal tersebut.

Kegiatan Pengabdian Kepada Masyarakat yang dilakukan oleh tim akademisi Fakultas IImu Komunikasi Universitas Padjadjaran memiliki target sebagai berikut: 
1) Ibu-ibu PKK di Desa Mekarmukti Kabupaten Bandung Barat menyadari pentingnya memiliki kemampuan berkomunikasi secara non verbal sehingga dapat berkomunikasi secara efektif.

2) Ibu-ibu PKK di Desa Mekarmukti Kabupaten Bandung Barat memahami cara berkomunikasi dengan baik sehingga informasi yang hendak disampaikan pada anggota lain maupun masyarakat yang berada dalam lingkungannya mencapai targetnya dengan efektif.

3) Ibu-ibu PKK di Desa Mekarmukti Kabupaten Bandung Barat memiliki kemampuan dalam mempersepsi seseorang tidak hanya melalui bahasa verbal, tapi juga melalui perilaku non-verbalnya.

4) Ibu-ibu PKK di Desa Mekarmukti Kabupaten Bandung Barat memiliki kemampuan dalam mengetahui suasana emosional seseorang yang mendorong utk mengenal lebih jauh.

Pengabdian Kepada Masyarakat dengan mengadakan Penyuluhan Kemampuan Komunikasi Non-Verbalbagi Ibu-ibu PKK di Desa Mekarmukti Kabupaten Bandung Barat ini diharapkan dapat menghasilkan luaran sebagai berikut:

1) Memberikan pengetahuan dan wawasan yang konkret mengenai komunikasi non verbal dan perkembangannya saat ini kepada lbu-ibu PKK di Desa Mekarmukti Kabupaten Bandung Barat.

2) Memberikan pengetahuan dan wawasan menyeluruh mengenai konsep-konsep komunikasi non verbal, dan tips berkomunikasi yang baik.

\section{METODE PELAKSANAAN}

Kegiatan penyuluhan Kemampuan Komunikasi Non-Verbalyang dilakukan ini, dengan mempertimbangkan materi penyuluhan, Ibu-ibu PKK di Desa Mekarmukti Kabupaten Bandung Barat sebagai audiens, masalah yang berkembang dan lingkungan yang mendukung, dalam pelaksanaannya akan menggunakan beberapa metode berikut :

1) Metode Ice Breaking dan Brain Storming mengenai apa itu komunikasi non verbal dan masalah-masalah yang berkaitan dengan komunikasi.

2) Metode presentasi dengan Power Point, yang memperlihatkan sebuah video yang berpusat pada seringnya terjadi kesalahphahaman dalam 
berkomunikasi ketika tidak menggunakan komunikasi non-verbal, khususnya dalam media sosial

3) Metode ceramah, dengan memberikan wawasan umum kepada Ibu-ibu PKK di Desa Mekarmukti Kabupaten Bandung Barat mengenai pentingnya memiliki kemampuan berkomunikasi non verbal serta perkembangannya dewasa ini.

4) Metode diskusi kelompok, di mana audiens diberikan kesempatan untuk bercerita mengenai pengalaman-pengalaman mereka ketika berkomunikasi baik pengalaman verbal, non verbal dan ketika memahami bahwa keduanya tidak dapat terpisahkan dan menceritakan hambatan-hambatan/friksi-friksi yang terjadi akibat tidak mengindahkan komunikasi non verbal.

5) Metode mengumpulkan feedback, di mana setelah selesai berdiskusi ibu-ibu mengutarakan pendapat mereka mengenai penyuluhan tersebut.

\section{HASIL DAN PEMBAHASAN}

Ibu-ibu PKK di Desa Mekarmukti Kabupaten Bandung Barat merupakan kelompok ibu-ibu pada masyarakat setempat yang aktif dalam setiap kegiatan desa. Mereka mengakui bahwa penggunaan media sosial dalam berkomunikasi antar para anggotanya merupakan salah satu media komunikasi yang sangat penting, mereka menggunakan fasilitas Black Berry Messenger (BBM) dan Whatsup sebagai media sosial mereka dalam komunikasi komunitas tersebut, maka daripada itu kami tim dosen dari UNPAD melakukan penyuluhan mengenai pentingnya komunikasi non verbal yang kadang kala diabaikan dalam berkomunikasi media sosial.

Penyuluhan tersebut diawali dengan 'ice breaking' mengenai komunikasi non verbal dan verbal, hal ini dilakukan untuk memahami apa itu komunikasi secara umum. Simbol, bahasa, atau pesan verbal adalah semua jenis simbol yang menggunakan satu kata atau lebih. Bahasa dapat juga dianggap sebagai sistem kode verbal (Deddy Mulyana, 2005), sedangkan komunikasi nonverbal adalah komunikasi yang menggunakan pesan-pesan nonverbal. Istilah nonverbal biasanya digunakan untuk melukiskan semua peristiwa komunikasi di luar kata-kata terucap dan tertulis. Secara teoritis, komunikasi nonverbal dan komunikasi verbal dapat dipisahkan. Namun dalam kenyataannya, kedua jenis komunikasi ini saling 
jalin menjalin, saling melengkapi dalam komunikasi yang kita lakukan sehari-hari

Penyuluhan kemudian dilanjutkan dengan "brainstorming" akan masalahmasalah yang timbul ketika berkomunikasi, khususnya dalam media sosial,yang tidak memiliki komunikasi non-verbal. Bagaimana kondisi yang media sosial yang tidak memfasilitasi hal-hal yang berkaitan dengan komunikasi non-verbal. Ibu-ibu PKK di Desa Mekarmukti Kabupaten Bandung Barat ini pun memberi contoh pengalaman komunikasi mereka dalam media sosial ketika terkadang mereka merasa tersingung ketika berkomunikasi dalam media sosial karena tidak adanya pesan non verbal yang mendukung sebuah pesan verbal dalam hal ini tulisan.

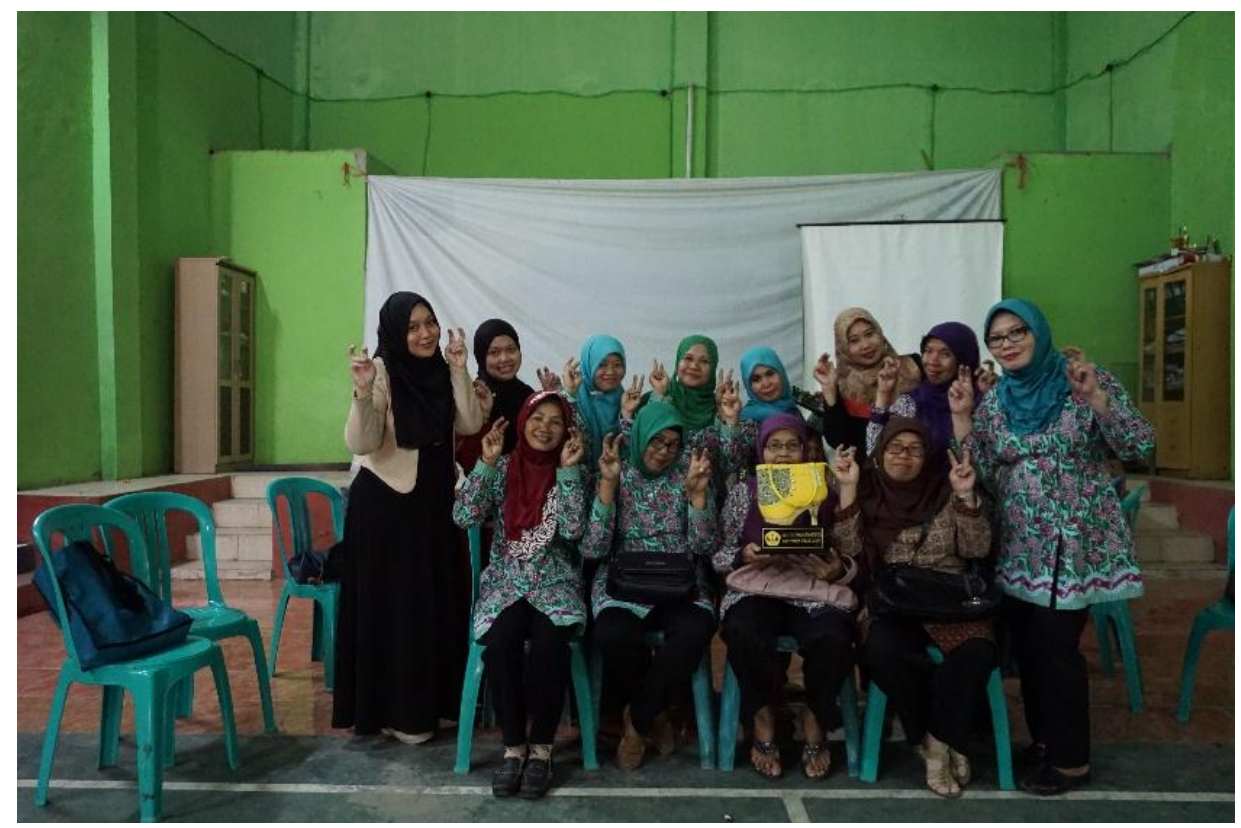

Gambar 1. Kegiatan Penyuluhan Kompetensi Komunikasi Non Verbal

Tim dosen Fikom Unpad memperlihatkan sebuah video yang merupakan Video dari film seri 'Friends' yang mencoba menggambarkan pentingnya komunikasi non verbal, Setiap adegan di 'pause' kemudian didiskusikan secara bersama-sama antara tim dosen dengan ibu-ibu PKK tersebut. Berikut adalah adegan-adegan yang digambarkan dalam film tersebut, yang menggarisbawahi bahwa kesalahphaman yang sering terjadi dalam komunikasi media sosial karena tidak memfasilitasi pesan-pesan non verbal: 
1) 'How does Ross convey shock without the use of his words', (Bagaimana Ross menunjukkan rasa syoknya tanpa kata) dalam adegan ini ketika Rachel (teman lawan wanitanya) berkata bahwa ia hamil, dan mengatakan bahwa Ross adalah bapaknya, Ross tidak mengatakan apa-apa hanya saja penonton dapat melihat bahwa ia terkejut dari raut muka yang menandakan bahwa dirinya sangat syok. Disini peran Facial Expression sangat besar, dimana ekspresi muka memberikan pesan yang mewakili perasaanya.

2) 'How does Joey convince Ross that 'he can do it", (Bagaimana Joey meyakinkan Ross bahwa ia bisa melakukannya). Dalam adegan ini Joey meyakinkan Ross bahwa ia dapat melakukan sesuatu dengan tatapan matanya yang tajam dan melotot terhadap Ross (eye contact). $\mathrm{Hal}$ ini menggambarkan bahwa tatapan mata seseorang selalu memiliki arti dan makna.

3) 'Whydoes Rachel's perception of the 'yeti' drastically changed', (Bagaimana persepsi Rachel terhadap 'yeti (semacam monster) tibatiba berubah). Dalam adegan tersebut, Rachel mempresepsikan seorang pria yang gondrong dan berjanggut lebat sebagai seseorag yang menakutkan dan mengatakannya sebagai monster sehingga ia tampak segan untuk bertemu dengannya, namun ketika pria tersebut memotong rambut dan janggutnya, Rachel langsung berpandangan lain. Hal ini membuktikan bahwa kita tidak bisa menilai seseorang dari penampilannya. Physical Appearance biasanya memberikan pesan tertentu pada seseorang tanpa mengetahui apakah pesan tersebut benar atau salah.

4) 'How does Ross know Phoebe is upset with him before she even says anything?', (Bagaimana Ross mengetahui bahwa Phoebe marah dengannya sebelum dia mengatakan apa-apa padanya). Dalam adegan ini, ketika Ross datang mendekati Phoebe, Phoebe langsung menghindarinya, dan pura-pura tidak melihatnya. Phoebe memberikan jarak (Spatial Behavior). Sehingga dengan jarak pun kita bisa melihat bahwa adanya pesan non verbal tertentu.

5) "How can we tell Ross is not "fine" even when he claims he is?" (bagaimana kita bisa mengetahui bahwa Ross sedih meskipun ia mengatakan sebaliknya?). Dalam adegan ini Rachel (mantan pacar Ross) berpacaran dengan teman baiknya, Ross bersih keras mengatakan bahwa ia baik-baik saja dengan keadaan tersebut, namun 
karena nada suaranya yang meninggi, kita bsa mengetahui bahwa perasaan sesungguhnya Ross adala sebaliknya, ia tidak baik-baik saja dalam keadaan tersebut. Ini pentingnya memahami apa yang disebut sebagai Paralinguistics: Pitchand Tone yakninada suara dan intonasi.

6) "How can we immediately tell Ross and Mike are both bored?". (Bagaimana kita mengetahui bahwa Ross dan Mike bosan?). Dalam adegan initerlihat Ross dan Mike duduk diatas sofa dengan postur tubuh yang 'malas-malasan; dan raut wajah yang sendu. Pesan non verbal tersebut menandakan bahwa mereka bosan, ini dinamakan Kinesics: Posture, dimana postur tubuh atau bahasa tubuh dapat memberikan pesan tertentu.

Pada akhir video tersebut ada ungkapan sebagai berikut: 'without the presence of these nonverbal cues, much of the communication in these scenes would simply not be possible', dimana dijelaskan bahwa tanpa adanya isyarat-isyarat non verbal dalam adegan-adegan tersebut, proses komunikasi tersebut tidak mungkin dapat terjadi.

Setelah mempertontonkan video tersebut, dilanjutkan dengan diskusi kelompok antara ibu-ibu PKK dan tim dosen yang berhubungan dengan pengalaman-pengalaman mereka dalam berkomunikasi. Adapun materi lain yang disampaikan kepada ibu-ibu PKK ini yang berhubungan dengan video yang dipertontonkan kepada mereka:

Jalaludin Rakhmat (1994) mengelompokkan pesan-pesan nonverbal sebagai berikut:

1) Pesan kinesik. Pesan nonverbal yang menggunakan gerakan tubuh yang berarti, terdiri dari tiga komponen utama: pesan fasial, pesan gestural, dan pesan postural.

2) Pesan fasial menggunakan muka untuk menyampaikan makna tertentu. Ekspresi muka dapat memberikan pesan kebagiaan, rasa terkejut, ketakutan, kemarahan, kesedihan, kemuakan, pengecaman, minat, ketakjuban, dan tekad.

3) Pesan gestural menunjukkan gerakan sebagian anggota badan seperti mata dan tangan untuk mengkomunikasi berbagai makna.Gerakan tubuh pada umumnya sulit untuk dipahami, namun gerakan tubuh merupakan sebuah simbol yang sudah menjadi sebuah kebiasaan dan disetujui secara bersama menurut komunitas dan budaya masingmasing. Seperi contohnya ketika kita melambaikan tangan, ini memiliki 
arti bahwa orang tersebut sedang memanggil, menyapa atau menyatakan selama tinggal. Sehinnga dalam memaknai sebuah gerakan tubuh, kita harus terlebih dahulu memahami kebudayaan apa yang mereka anut.

4) Pesan postural berkenaan dengan keseluruhan anggota badan, makna yang dapat disampaikan adalah: a. Immediacy yaitu ungkapan kesukaan dan ketidaksukaan terhadap individu yang lain. Postur yang condong ke arah yang diajak bicara menunjukkan kesukaan dan penilaian positif; b. Power mengungkapkan status yang tinggi pada diri komunikator. Anda dapat membayangkan postur orang yang tinggi hati di depan anda, dan postur orang yang merendah; c. Responsiveness, individu dapat bereaksi secara emosional pada lingkungan secara positif dan negatif. Bila postur anda tidak berubah, anda mengungkapkan sikap yang tidak responsif.

5) Pesan proksemik disampaikan melalui pengaturan jarak dan ruang. Umumnya dengan mengatur jarak kita mengungkapkan keakraban kita dengan orang lain.

6) Pesan artifaktual diungkapkan melalui penampilan tubuh, pakaian, dan kosmetik. Walaupun bentuk tubuh relatif menetap, orang sering berperilaku dalam hubungan dengan orang lain sesuai dengan persepsinya tentang tubuhnya (body image). Erat kaitannya dengan tubuh ialah upaya kita membentuk citra tubuh dengan pakaian, dan kosmetik.

7) Pesan paralinguistik adalah pesan nonverbal yang berhubungan dengan dengan cara mengucapkan pesan verbal. Satu pesan verbal yang sama dapat menyampaikan arti yang berbeda bila diucapkan secara berbeda. Pesan ini oleh Dedy Mulyana (2005) disebutnya sebagai parabahasa.

8) Pesan sentuhan dan bau-bauan.Alat penerima sentuhan adalah kulit, yang mampu menerima dan membedakan emosi yang disampaikan orang melalui sentuhan. Sentuhan dengan emosi tertentu dapat mengkomunikasikan: kasih sayang, takut, marah, bercanda, dan tanpa perhatian.

Penyuluhan mengenai materi tersebut berlangsung kurang lebih dua jam, yang diikuti oleh partisipasi aktif dari para lbu-ibu PKK di Desa Mekarmukti Kabupaten Bandung Barat. Penyuluhan inipun kemudian diakhiri feedback 
langsung sebagai upaya untuk pada kemudian hari penyuluhanpenyuluhan serupa dapat berlanjut dan mengumpulkan materi-materi apa yang dibutuhkan oleh mereka. Pada akhirnya ditutup dengan foto bersama dan penyerahan suvenir.

\section{SIMPULAN}

Hasil dari pengabdian pada masyarakat ini terlihat bahwa:

Ibu-ibu PKK di Desa Mekarmukti Kabupaten Bandung Barat ini sadar akan pentingnya memiliki pengetahuan akan kemampuan berkomunikasi non verbal baik dalam media sosial maupun sehari hari.

Ibu-ibu PKK di Desa Mekarmukti Kabupaten Bandung Barat secara aktif ikut terlibat dalam setiap diskusi mengenai pengalaman-pengalaman mereka akan konflik yang terjadi di media sosial karena absennya isyaratisyarat komunikasi non verbal.

Para ibu PKK di Desa Mekarmukti Kabupaten Bandung Barat tertantang untuk terlibat dalam penyuluhan-penyuluhan yang bertemakan komunikasi efektif yang dalam media sosial dan mengaplikasikannya dalam grup BBM atau Whatsapp mereka, karena akan bermanfaat bagi keefektifan komunikasi mereka dalam komunitas ibu-ibu PKK di Desa Mekarmukti Kabupaten Bandung Barat.

Penyuluhan ini memberi tolak ukur seberapa jauh lbu-ibu PKK di Desa Mekarmukti Kabupaten Bandung Barat memahami pentingnya memiliki kemampuan berkomunikasi baik verbal maupu non verbal.

Adapun saran yang ingin diberikan yakni perlunya penyuluhan komunikasi verbal dan non verbal yang terus berkelanjutan melihat kemajuan teknologi dan informasi sangat pesat.

\section{REFERENSI}

Effendy, O. (1994). Ilmu komunikasi: Teori dan praktek. Bandung: Remaja Rosdakarya.

Knapp, M. L. (1992). Nonverbal communication in human interaction. United State of America: Harcourt Brace Jovanovuch College Publishera. 
Penyuluhan Kompetensi Komunikasi Non Verbal bagi Masyarakat di Desa Mekarmukti, Bandung Barat

Mulyana, D. (2005). IImu komunikasi: Suatu pengantar. Bandung: Remaja Rosdakarya.

Rakhmat, J. (1994). Psikologi komunikasi. Bandung: Remaja Rosdakarya. 